\title{
Improving Students' Spatial Ability with GeoGebra Software
}

\author{
Yerizon $^{1, *}$, Fitrani Dwina ${ }^{1}$, Nor'ain Mohd. Tajudin ${ }^{2}$ \\ ${ }^{1}$ Department of Mathematics, Universitas Negeri Padang, Indonesia \\ ${ }^{2}$ Department of Mathematics, Sultan Idris Education University, Malaysia
}

Received November 8, 2020; Revised December 17, 2020; Accepted January 20, 2021

\section{Cite This Paper in the following Citation Styles}

(a): [1] Yerizon, Fitrani Dwina, Nor'ain Mohd. Tajudin, "Improving Students' Spatial Ability with GeoGebra Software," Universal Journal of Educational Research, Vol. 9, No. 1, pp. 129 - 135, 2021. DOI: 10.13189/ujer.2021.090114.

(b): Yerizon, Fitrani Dwina, Nor'ain Mohd. Tajudin (2021). Improving Students' Spatial Ability with GeoGebra Software. Universal Journal of Educational Research, 9(1), 129 - 135. DOI: 10.13189/ujer.2021.090114.

Copyright $\mathrm{O} 2021$ by authors, all rights reserved. Authors agree that this article remains permanently open access under the terms of the Creative Commons Attribution License 4.0 International License

\begin{abstract}
Technology plays a significant role in all aspects of human life, including the education world. For instance, the use of computer media in the learning process is very useful for improving students' mathematical abilities such as GeoGebra. Therefore, this research aims to describe the results of various studies on the usage of GeoGebra software as a mathematical learning tool to improve students' spatial abilities. This is a descriptive research where intensive and rigorous literatures were reviewed, with data collected from previous studies on GeoGebra software's effect on learning mathematics. Several related electronic databases were explored to investigate for the relevant articles. The relevant articles identified use the snowballing method. The result showed that the use of GeoGebra software is one of the most frequently used technologies in the mathematics classroom as well as in other fields of science because of the great potential of this software in helping students to master important mathematical concepts and offer features specific to mathematical concepts for mathematics learning. The use of GeoGebra helps students understand mathematical material and improve spatial abilities, visualize and animate mathematical objects as well as motivates students to learn mathematics using GeoGebra.
\end{abstract}

Keywords Spatial Ability, GeoGebra, Mathematics

\section{Introduction}

Geometry, as one of the mathematics topics, is difficult for students to understand, visualize, and construct geometric shapes $[1-7]$. These difficulties are closely related to their weak and spatial abilities to understand geometry, such as illustrating the shape of a hollow three-dimensional space [8]. According to Suryobintoro [9], students need to come in direct contact with objects in order to think and provide abstract ideas regarding the shape and other characteristics.

Several studies have been carried out on students' difficulties in learning geometry. Putri [10] stated that many junior high school students find it challenging to solve problems related to parallel lines and claim that the rhombus is not a parallelogram. Furthermore, Marika [11] stated that students find it challenging to describe the shape of space, especially the building area. This is also similar to the research carried out by Sugiarni [12], which reported that students find it difficult to transform and provide final conclusions related to geometric objects. Their weakness is also found in the formula for the surface area of cubes and blocks [13], as well as drawing graphs, determining gradients and equations from straight-line graphs [14]. Students also find it difficult to solve problems related to the surface area of spaces, frameworks, the volume of space structures, and the relationships between objects [15]. 
According to Putri [10], students' difficulty in learning geometry material hinders them from understanding other mathematical topics. They also tend to memorize the various formulas and work procedurally to understand mathematics without reasoning [13],[16].

Gardner stated that spatial ability is precisely used to capture the world of space and to visualize images. This includes the appropriate recognition of objects shape, with their real form description [17 - 19],[6 - 7]. Spatial ability is needed to solve mathematical problems, especially on geometry [20] and it is closely related to academic achievement [1]. [21, 22]. An increase in logical-mathematical intelligence leads to a rise in students' spatial abilities [17]. Consequently, there is a strong relationship between spatial ability and mathematics performance [21].

Presently, mathematics is largely taught by teachers in schools using materials, practice questions, and by issuing homework $[3,16,6,23,11]$. This process tends to affect the role of teachers and school facilities in developing technology and learning media for solving mathematical problems [12]. Furthermore, students are less actively involved in building ideas to determine the concept of the cube and block surface area, with pictures made by teachers on the blackboard as an illustration. Therefore, it is necessary to use interactive media developed as computer software in learning. One of such techniques is the GeoGebra used in learning mathematics $[24,18,14,6$, $15,25,12,11,26]$. GeoGebra is a dynamic and interactive software developed by Markus Hohenwarter in 2001 to support the act of learning and solving mathematical problems, such as geometry, algebra, and calculus [27 $29,18,30,24,14,31,32,13,5,33-35]$.

Due to its various facilities, GeoGebra can be used as a medium for learning, demonstrating, or visualizing geometric concepts $[28,18,24,36,2,37,32,38,39,15$, $38,39,15,40-44]$. This means that GeoGebra is useful as 1) a media of demonstration and visualization, 2) construction, 3) invention process, as well as 4) communication and representation [14, 13, 25, 23, 45, 12]. GeoGebra has the advantage of being able to describe objects in two to three-dimensional space, thereby making it easy for students to determine abstract objects that are difficult to describe manually [16]. This software is user friendly and can improve students' conceptual understanding, critical thinking skills, and learning activities $[28,9,46,40]$. It can also be used to teach and learn mathematics to make the process easier for students to understand the concepts quickly and correctly, thereby providing an interactive learning environment [47]. Furthermore, this software provides accurate calculations, making it easier for students to effectively analyze geometric problems [23]. This research analyzes the various effect of using GeoGebra in mathematics learning on students' spatial abilities.

\section{Materials and Methods}

This study was carried out to determine various results on GeoGebra's use in mathematics learning to improve spatial abilities. The intensive and rigorous literature review were done to analyze the usage of GeoGebra software in teaching and learning mathematics both locally and abroad in general and in the field of mathematics education. There were two methods that were used to search the relevant and appropriate literature of the research. These approaches were suggested by Page (2008) and well thought-out as the suitable and efficient ways to ascertain significant literature.

At the first phase, several related electronic databases were explored to investigate for the relevant articles, such as EBSCO host, Elsevier, Science Direct, Emerald, JSTOR, ProQuest, Sage Publications, SciVerse, Scopus, Springer Link, Taylor and Francis Online and Wiley Online. The main keywords used were GeoGebra, technology in mathematics teaching and learning, twenty-first century teaching and learning, the effective teaching and learning in general and specifically in mathematics subject at primary to higher institution level. Furthermore, each single journal was examined individually to find more pertinent papers, for example, International Electronic Journal of Mathematics Education, Mathematics Education, Eurasia Journal of Mathematics, Science \& Technology Education, Procedia-Social and Behavioral Sciences, Asian Social Science, etc.

At the second phase, the relevant articles were identified based on the pull out bibliography of the crucial articles of the above literature review using the snowballing method. The literature exploration was done from 2019 to 2020 and restricted to only teaching and learning studies available between 2009 and 2019. This leads to the limitation of this study. If it is found that an article fulfilled these three elements: (a) it focused predominantly on the usage of GeoGebra in teaching and learning of mathematics in general and specifically in mathematics subject at all levels, (b) the investigation was carried out in the venue of primary to higher institutions and among mathematics educators, then this article will be included in this study. The peer-reviewed articles that were published in academic journals were also included. Furthermore, conference proceedings, and theses, were also included from this review. Duplication, indistinguishable and identical publications that were irrelevant were removed. Those articles were selected for relevance, essentially based on the title, abstracts, and keywords.

\section{Results and Discussion}

Several studies show that GeoGebra is very effective in learning mathematics [49 - 52]. Furthermore, previous research has proven that GeoGebra has a positive 
influence on student learning outcomes [53, 54], and improves their understanding regarding the circle's concept and visualization abilities of junior high school students [55]. It also increases their conceptual and procedural knowledge through the Brain-Based Learning approach [56]. In addition, the research carried out by Astuty and Rudhito [57] stated that the GeoGebra program overcomes student's difficulties in learning straight line material, especially in visualizing the graphs [14].

Research on using GeoGebra to improve students' spatial abilities were conducted severally $[18,2,58,19$, $13,6,15,25,23,12,59,11,26,24]$. Ristontowi [18] carried out an experiment on grade eight students of Junior High School to determine the difference in their increasing spatial abilities on the use of the RME approach with and without GeoGebra. The result showed no difference in the improvement of students' spatial abilities without using GeoGebra media through the RME approach.

Similarly, Prakoso [2] researched grade nine students of Junior High School to determine their mathematical spatial abilities through GeoGebra's learning geometry. The result showed that teachers needed more time to explain the material and discuss mathematical problems in the control class compared to the experimental class. Therefore, the following was concluded 1) The mathematical spatial ability of students taught with GeoGebra is better than conventional learning. 2) Students have a positive attitude towards geometry and problems with GeoGebra's mathematical spatial abilities due to their enthusiasm for using the tool. Fajri [58] conducted an experiment on grade eight students of Junior High School to determine the increase in spatial abilities and self-efficacy through the application of the GeoGebra-assisted discovery learning model. Samples were obtained using the random sampling techniques, and based on analysis, the increase in students' spatial abilities and self-efficacy by applying the GeoGebra-based discovery learning model was better and had no connection. Sumarni [19] researched to diagnose students' visual-spatial thinking abilities and described efforts to improve their learning outcomes in spatial geometry courses. The results showed that: a) Students' had low and moderate visual-spatial thinking abilities with difficulty in solving problems related to the concept of plumb lines and projections. Furthermore, it determined the distance of points, lines, and planes, as well as the angle between the line and the plane. b) Visual-spatial thinking is an ability that needs to be developed in studying spatial geometry and one of the causes of low learning outcomes c) One of the efforts used to improve students' visual-spatial thinking skills is learning spatial geometry through problem-based learning with the help of GeoGebra software.

In another study carried out by Asryana [13], an experimental research was done on the development of interactive learning media with GeoGebra used to improve students' spatial abilities. The analysis results of the development of learning media are as follows: a) based on the assessment of media and material experts, the criteria are very valid. b) student assessment is a device effectively used to obtain the needed criteria. Therefore, it can be concluded that the learning media met valid and effective quality and can be used in schools.

Furthermore, Siswanto [6] conducted research on grade eight students of Junior High School to determine the effect of guided inquiry learning with GeoGebra assistance on improving their spatial geometry abilities. The results showed that students' spatial geometry abilities received guided inquiry learning with GeoGebra assistance significantly better than the conventional.

Recently, Haris [15] carried out an experiment to support the increase in students' spatial abilities through Problem Based Learning (PBM) with the help of GeoGebra. The results showed that (1) the use of PBM on GeoGebra assisted geometry material had an effect on spatial abilities, (2) conventional learning methods affected spatial abilities, and (3) PBM on GeoGebra-assisted geometry had a more significant effect than the conventional.

In a similar study by Himmi [25], a research was conducted related to the development of a GeoGebra-based two-variable inequality system module on the mathematical visual thinking abilities of grade ten students. Module development was carried out based on the ADDIE model with analysis, design, development, implementation, and evaluation stages. The results showed that the module was very valid (3.46), practical (3.04), and effective (89\%), with a class average of 89.61 .

Jelatu [23] carried out an experiment to determine GeoGebra media integration's effect on understanding geometric concepts on grade nine students of Junior High School. The results showed that: 1) Understanding students' geometry concept that takes learning assisted by GeoGebra media is better than conventional learning. 2) There is no interaction between learning assisted by GeoGebra media and students 'spatial abilities on the understanding of geometric concepts. Sugiarni [12] conducted a research using class XI IIS students of Senior High School to understanding their mathematical spatial abilities using the GeoGebra-assisted Problem Based Learning model. The results showed that students' spatial abilities improved by applying the problem-based learning model assisted by GeoGebrain each cycle. The classical absorption of students in cycle I, II, and III were $53 \%$, $76 \%$, and $82 \%$. Furthermore, student and teacher activities with the Problem-based Learning model assisted by GeoGebra can run effectively and conductively. Student responses in learning geometry with the assistance of this GeoGebra generally produce a positive impression.

Tonra [59] carried out a research related to the 
development of calculus student worksheets (LKM) in addition to the GeoGebra software to improve spatial abilities. This development research refers to the 4-D device development model (Four D Model) and the result showed that (1) The developed LKMs are categorized as good and very good according to the validation results by experts therefore they are suitable for classroom learning (2) There are changes before and after using LKM on learning outcomes to improve student spatial abilities. (3) Increasing in spatial ability after being provided with LKM assisted by GeoGebra software is in the medium category.

Marika [11] conducted research on grade twelve students of vocational high school to produce mathematics teaching materials with a scientific approach using valid GeoGebra software capable of improving their geometric spatial abilities. Furthermore, the study was carried out using a 4-D development model (Four-D Model). The expert/validator's assessment results showed that the teaching materials were valid as determined from the students' responses, which is in the positive category. Furthermore, the teaching materials' effectiveness results based on student activity are in the high category with a spatial ability test score of $86.11 \%$. The research also showed an increase in the valid, practical, and effective use of teaching materials in the experimental class with significant differences between students taught by learning a scientific approach using GeoGebra software and conventional learning.

Handayani [26] carried out a research on grade twelve students of vocational high school to determine the effect of the GeoGebra-assisted Problem Based Learning (PBL) model and learning motivation on spatial abilities in three-dimensional material. The results showed (1) There was no significant difference in spatial ability using the Problem Based Learning or conventional models. (2) There is no significant difference in the category of student learning motivation using the Problem Based Learning or the conventional model on spatial abilities. (3) There is no interaction between the learning model and motivation. Therefore, any learning model and motivation category is acceptable.

Asngari [24] researched grade eight students of Islamic Junior High School to develop LKPD (student's worksheet) in mathematics learning materials of flat-sided geometry using valid and practical GeoGebra and tested the effectiveness of Visual Thinking skills. The results showed that the LKPD developed was in the valid category and fulfilled the practical aspects. This can be seen from the following 1) the implementation of learning in limited trials is classified as practical and in a small group, 2) the use of LKPD in mathematics learning developed in terms of students' responses is classified as practical and effective against students' Visual Thinking abilities.
Students have a lot of problems with spatial abilities especially on three dimensions [60]. Even students who are gifted with mathematics also have difficulty imagining three-dimensional objects in space from their drawings in two-dimensional space in the plane [21]. For example, in the cube image, it appears that the image is slightly tilted, not right angled like the original. Then the sides didn't seem to be the same length either [61]. Students find it difficult to imagine the shape of objects from different perspectives [1].

There are several aspects of students' difficulties in spatial abilities including spatial visualization, spatial perception, and spatial relations. Spatial visualization defined as the ability to imagine an image about the location (the part that is not visible from the front) or the parts that have changed (the part of the side that is not visible from the front must be draw as dashes) of a shape of the space. Students have difficulty in determining which parts should be draw as dashes. The difficulty of students in spatial perception ability is that students do not understand which lines / segments / parts are located in a horizontal or vertical position in a shape. The difficulty of students in spatial relations skills is that students do not understand that two lines will intersect if they are located on the same plane. Students also do not understand the parts of space and their relationship between one part and another [8]. With GeoGebra and other software such as Cabri 3D, teachers can more effectively introduce three-dimensional geometric shapes to students and can clearly show three-dimensional geometric drawings that are usually difficult to draw on the blackboard. Softwares in learning geometry can provide good enough visual power for students [62]. Students can visualize a geometric object well, thus avoiding misconceptions [63]. Thus students can see the shape of the room from a different point of view so that students know what shape is described [64].

\section{Conclusions}

The rapid development of technology in education has led to various technology tools invented for the purpose of education, especially in mathematics. In this era, the use of GeoGebra software is one of the most frequently used technologies in the mathematics classroom as well as in other fields of science because of the great potential of this software in helping students to master important mathematical concepts and offer features specific to mathematical concepts for mathematics learning. In summary, this study highlighted several important points that the use of GeoGebra software can enhance students' mathematical abilities such as:

1. It helps students understand mathematical material and improve spatial abilities.

2. Visualizing and animate mathematical objects.

3. Motivating students to learn mathematics using GeoGebra. 


\section{Acknowledgements}

This research was supported by Universitas Negeri Padang in accordance with the research contract number 1415/UN35.13/LT/2020, fiscal year 2020.

\section{REFERENCES}

[1] E. Febriana. Spatial Ability Profile of Junior High School Students in Solving Problems of Three Dimensions Geometry in Terms of the Mathematics Ability. Jurnal Elemen, 1(1), 13-23, 2015.

[2] W.D. Prakoso, M.Y.D. Putra, A. Mentari \& B. Rahman. Improving Mathematical Spatial Ability through GeoGebra-Assisted Geometry Learning. Seminar Nasional Matematika dan Pendidikan Matematika UNY, 497-504, 2015.

[3] D. Pianda. Using Geogebra through a Scientific Approach to Improve Mathematics Learning Outcomes. Indonesian Digital Journal of Mathematics and Education, 3 (4), 273-284, 2016.

[4] R.D. Siswanto \& Y.S. Kusumah. Association between Spatial Ability in Geometry with Student's Mathematical Creative Thinking. KALAMATIKA Jurnal Pendidikan Matematika, 1(2), 141-146, 2016.

[5] N. Japa, Suarjana \& Widiana. Geogebra in Mathematics Learning. International Journal of Natural Science and Engineering, 1(2), 40-47, 2017.

[6] R.D. Siswanto \& Y.S. Kusumah. Increasing Spatial Ability in Geometry of Junior High School Students through GeoGebra-Assisted Guided Inquiry Learning. JPPM, 10 (1), 42-51, 2017.

[7] S.K. Putri, Hasratuddin \& E. Syahputra. Development of Learning Devices Based on Realistic Mathematics Education to Improve Students' Spatial Ability and Motivation. International Electronic Journal of Mathematics Education, 14 (2), 393-400, 2019.

[8] M. Imamuddin \& Isnaniah. Spatial Ability Profile of Camper Students in Reconstructing Prism Slices in terms of Gender Differences. Jurnal Matematika dan Pembelajaran, 6 (1), 31-39, 2018.

[9] A. Suryobintoro \& M.A. Rudhito. Utilization of GeoGebra in Improving Understanding of Triangle in terms of Student's Learning Outcome in VII Grade. Prosiding Seminar Nasional Sains dan Pendidikan Sains VIII, Fakultas Sains dan Matematika, UKSW Salatiga, 4 (1), 195-201, 2013.

[10] A.H. Putri. Effect of Spatial Ability on Geometry for VIII Grade Junior High School Students in the Kebomas Gresik. Didaktika, 23 (2), 114-121, 2017.

[11] D.O. Marika, S. Haji \& D. Herawaty. Development of Teaching Materials with GeoGebra-Assisted Scientific Approach to Improve Spatial Ability. Jurnal Pendidikan Matematika Raflesia, 4 (2), 153-163, 2019.

[12] R. Sugiarni, E. Alghifari \& R.A. Ifanda. Improving
Student's Mathematical Spatial Ability with GeoGebra-Assisted Problem Based Learning. KALAMATIKA Jurnal Pendidikan Matematika, 3 (1), 93-102, 2018

[13] Asryana, Sanapiah \& I.P. Kinasih. Development of Interactive Learning Media Using GeoGebra to Improve Student's Spatial Ability. Media Pendidikan Matematika, 5 (2), 107-114, 2017.

[14] U. Farihah. Effect of Interactive GeoGebra on Student's Motivation and Learning Outcome on Graph of Straight Line Equation. Jurnal Pendidikan dan Pembelajaran Matematika (JP2M), 1 (1), 11-23, 2015.

[15] A. Haris \& A. Rahman. Student's Spatial Ability through Problem Based Learning Using GeoGebra Software. Prosiding Seminar Nasional Lembaga Penelitian dan Pendidikan (LPP) Mandala, 1-7, 2018.

[16] V.D. Mawarsari \& E.A. Purnomo. Utilization of E-learning Assisted Geogebra Software in Geometry Learning. JKPM, 4 (2), 1-5, 2017.

[17] J. Harmony \& T. Roseli. Effect of Spatial Ability on Student's Mathematical Learning Outcome in VII Grade Junior High School 9 Jambi. Edumatica, 2 (1), 11-19, 2012.

[18] Ristontowi. Student's Spatial Ability through Realistic Mathematic Education Approach with GeoGebra. Prosiding Seminar nasional Matematika dan Pendidikan Matematika FMIPA UNY, 2013.

[19] Sumarni \& A.T. Prayitno. Visual-Spatial Thinking Ability in Space Geometry for Universitas Kuningan Students. JES-MAT, 2 (2), 81-100, 2016.

[20] A.I. Alfaruqi \& M. Lutfianto. Comparison of Student's Spatial Ability on Geometry in terms of Student's Learning Style. Seminar Nasional Pendidikan Matematika Ahmad Dahlan, 13-17, 2016.

[21] S. Danisman \& E. Erginer. The predictive power of fifth graders' learning styles on their mathematical reasoning and spatial ability. Cogent Education 2017, 4:1266830, 1-18, 2017.

[22] Y. Ariani, R. Johar \& Marwan. The Use of Cabri 3D Software to Improve Spatial Ability of Junior High School Student. Jurnal Peluang, 7 (2), 11-21, 2019.

[23] S. Jelatu, Sariyasa \& I.M. Ardana. Effect of Using GeoGebra on Understanding Geometry Concept in terms of Student's Spatial Ability. Jurnal Pendidikan dan Kebudayaan Missio, 10 (2), 137-273, 2018.

[24] D.R. Asngari, F. Keguruan \& U.L. Unila. The Use of GeoGebra in Geometry Learning, 299-302, 2015.

[25] N. Himmi \& L.B.A. Hatwin. Development of Linear Inequality System with Two Variables Modul with GeoGebra-Based on Mathematical Visual Thinking Ability of X Grade Students. Pythagoras, 7(1), 35-46, 2018.

[26] A. Handayani, Sunandar \& Sutrisno. The Effect of GeoGebra-Assisted Problem Based Learning (PBL) and Learning Motivation on Spatial Ability in Three-Dimensional. Imajiner: Jurnal Matematika dan Pendidikan Matematika, 2(4), 286-291, 2020.

[27] V. Antohe. Limits of Educational Soft GeoGebra in A 
Critical Constructive Review. Anale Seria Informatieà, 7(1), 47-54, 2009.

[28] L. Dikovic. Applications GeoGebra into Teaching Some Topics of Mathematics at the College Level. ComSIS, 6 (2), 191-203, 2009.

[29] F.D. Permadi \& M.A. Rudhito. Effectiveness of Learning with GeoGebra Compared with Conventional Learning on Pythagoras Theorem in VIII Grade Junior High School Pangudi Luhur Gantiwarno Klaten. Seminar Nasional Matematika dan Pendidikan Matematika UNY, 326-334, 2012.

[30] Putri, N.W. Suardiati, Sariyasa \& I.M. Ardana. Development of Tandur Learning Design with GeoGebra- Assisted to Improve Student's Achievement and Learning Activities in Geometry. e-Journal Program Pascasarjana Universitas Pendidikan Ganesha, 3 (1), 2014.

[31] A.I. Adegoke. GeoGebra: The Third Millennium Package for Mathematics Instruction in Nigeria. Anale Seria Informatic?, 14 (1), 35-43, 2016.

[32] H. Sandir \& S. Aztekin. Pre-Service Math Teachers' Opinions about Dynamic Geometry Softwares and Their Expectations from Them. IEJME-Mathematics Education, 11(3), 421-431, 2016.

[33] N. Nari. Using Geogebra Software for Geometry Lectures. 2 nd International Seminar on Education 2017: Empowering Local Wisdom on Education for Global Issue, 1(2), 307-314, 2017.

[34] M.A. Alkhateeb \& A.M. Al-Duwairi. The Effect of Using Mobile Applications (GeoGebra and Sketchpad) on the Students' Achievement. International Electronic Journal of Mathematics Education, 14(3), 523-533, 2019.

[35] M. Khalil, U. Khalil \& Z. Haq. GeoGebra as A Scaffolding Tool for Exploring Analytic Geometry Structure and Developing Mathematical Thinking of Diverse Achievers. International Electronic Journal of Mathematics Education, 14(2), 427-434, 2019.

[36] K.K. Bhagat \& C. Chang. Incorporating GeoGebra into Geometry learning-A lesson from India. Eurasia Journal of Mathematics, Science \& Technology Education, 11(1), 77-86, 2015.

[37] A. Mahmudi. Utilization of GeoGebra in Mathematics Learning. Jurnal Matematika dan Pendidikan Matematika, 5(1), 10-19, 2016

[38] J. Sihwidi. Using GeoGebra to Increase Activities and Mastery of Geometry Transformation Competencies at SMKN 1 Tulang Bawang Tengah. Indonesian Digital Journal of Mahematics and Education, 3(4), 208-220, 2016.

[39] E. Tatar \& Y. Zengin. Conceptual Understanding of Definite Integral with GeoGebra. Computers in the Schools, 33(2), 120-132, 2016.

[40] D.W. Hidayati \& L. Kurniati. Application of GeoGebra-Assisted Spatial Geometry Teaching Materials on Field Slices Material in Space Buildings. Seminar Nasional Edusainstek FMIPA UNIMUS, 121-127, 2018.

[41] U. Kul. Influences of Technology Integrated Professional Development Course on Mathematics Teachers. European Journal of Educational Research, 7(2), 233-243, 2018.
[42] Y.A. Wassie \& G.A. Zergaw. Some of the Potential Affordances, Challenges, and Limitations of Using GeoGebra in Mathematics Education. EURASIA Journal of Mathematics, Science and Technology Education, 15(8), $1-11,2019$.

[43] M.T.S. Wondo, M.F. Mei \& S.B. Seto. The Use of GeoGebra in Space Geometry Learning to Increase Student's Interest and Learning Outcomes. Jurnal Pendidikan Matematika, 11 (2), 163-171, 2020.

[44] S.T. Yimer \& N.N. Feza. Learners' Conceptual Knowledge Development and Attitudinal Change toward strategy Integrated with GeoGebra. International Electronic Journal of Mathematics Education, 15(1), 1-26, 2020.

[45] D. Nopiyani, T. Turmudi \& S. Prabawanto. Application of Geogebra-Assisted Realistic Mathematic Learning to Improve the Mathematical Communication Ability of Junior High School Students. Mosharafa: Jurnal Pendidikan Matematika, 5(2), 45-52, 2018.

[46] I.H. Batubara. Mathematical Critical Thinking Ability through Problem Based Learning Using Autograph and GeoGebra in Senior High School Freemethodist Meda. Wahana Inovasi, 6(1), 97-105, 2017.

[47] D. Lognoli. The Area of the Disk in Middle School Grade by GeoGebra. iJET, 12 (11), 28-40, 2017.

[48] D. Page. Systematic Literature Searching and the Bibliographic Database Haystack. The Electronic Journal of Business Research Methods, 6(2), 171-180, 2008.

[49] H. Zulnaidi \& E. Zakaria. The Effect of Using GeoGebra on Conceptual and Procedural Knowledge of High School Mathematics Students. Asian Social Science, 8(11), 102-106, 2012.

[50] R.A. Saha, A.F. Ayub \& R.A. Tamizi. The Effects of GeoGebra on Mathematics Achievement: Enlightening Coordinate Geometry Learning. Procedia-Social and Behavioral Sciences, 8, 686-693, 2010.

[51] Y. Zengin, H. Furkan \& T. Kutluca. The Effect of Dynamic Mathematics Software GeoGebra on Student Achievement in Teaching of Trigonometry. Procedia-Social and Behavioral Sciences, 31, 183-187, 2012.

[52] M. Ana \& F.T. Ángel. Teaching Numerical Methods for Non-Linear Equations with GeoGebra Based Activities. Mathematics Education, 10(2), 53-65, 2015.

[53] Zerrin \& Sevinc. The Effect of The GeoGebra Use in Mathematics Education: a Case Study on Integers in Turkey, 2010.

[54] Y.T. Widyaningrum \& C.E. Murwanintyas. Effect of GeoGebra on Motivation and Learning Outcome of Students on Quadratic Function in X Grade Senior High School 2012/2013. Makalah dipresentasikan dalam Seminar Nasional Matematika dan Pendidikan Matematika pada tanggal 10 November 2012 di Jurusan Pendidikan Matematika FMIPA UNY, 2012.

[55] S. Gumanti. Effect of Geogebra-Assisted Learning on Improving Understanding and Visual Thinking of Senior High School Students. Tesis tidak dipublikasikan. Sekolah Pascasarjana. Universitas Pendidikan Indonesia, 2014.

[56] B. Darmansah. Effect of Using Brain-Based Learning 
Approach with GeoGebra-Assisted in Mathematic Learning on Conceptual and Procedural Knowledge of Senior High School Students. Tesis tidak dipublikasikan. Sekolah Pascasarjana, Universitas Pendidikan Indonesia, 2014.

[57] V.W.D. Astuty \& M.A. Rudhito. The Use of GeoGebra in Resolving Difficulties Learning of VIII Grade Junior High School Students 1 Nanggulan Kulon Progo on Learning Remedial Straight Line Graph. Makalah dipresentasikan dalam Seminar Nasional Matematika dan Pendidikan Matematika pada tanggal 10 November 2012 di Jurusan Pendidikan Matematika FMIPA UNY, 2012.

[58] H.N. Fajri, R. Johar \& M. Ikhsan. Increasing Student's Spatial Ability and Self-efficacy through Multimedia-Based Discovery Learning. Beta, 9 (2), 180-196, 2016.

[59] W.S. Tonra \& A. Salim. Development of GeoGebra-Assisted Calculus Student Worksheet to Improve Spatial Ability. Jurnal Saintifik, 4 (2), 156-166, 2018.

[60] M. Asis, N. Arsyad \& Alimuddin. Spatial Ability Profile in Solving Geometry Problems of Students Who Have High
Intelligences Logical-Mathematical in terms of Gender Differences. Jurnal Daya Matematis, 3(1), 78-87, 2015.

[61] D. Rikanah \& W. Winarso. Mastery of Circle Concepts on Student's Mathematical Spatial Ability on Curved Sides Space Geometry in VIII Grade Junior High School 1 Cirebon. Jurnal Pendidikan Matematika, 10 (1), 15-27, 2016.

[62] Y. Ariani, R. Johar \& Marwan. Use of Cabri 3D Software to Improve the Spatial Ability of Junior High School Students. Jurnal Peluang, 7 (2), 11-21, 2019.

[63] G. Dwirahayu, L. Himawan \& D. Kustiawati. Geometry Learning with Wingeom Media to Improve Student's Visual Representation Ability. Seminar Nasional Fakultas Ilmu Tarbiyah dan Keguruan UIN Syarif Hidayatullah Jakarta, 2018.

[64] D. Nopitasari \& W. Saefuddin. Application of Computer Assisted Mathematics Learning Through the Cabri 3D Program on Spatial Ability and Independent Learning. Jurnal Teori dan Riset Matematika (TEOREMA), 2 (1), 22 $-28,2017$. 